\title{
CHARACTERISTICS OF BREAST CANCER IN BRCA1/BRCA2 MUTATION CARRIERS AND NON-CARRIERS FROM A GENETIC COUNSELING UNIT IN CROATIA
}

\author{
SNJEŽANA RAMIĆ1,5, GABRIELA ALFIER ${ }^{2,5}$, IVA KIRAC ${ }^{3,5}$, IVAN MILAS ${ }^{2,5}$, \\ PETRA VUKOVIĆ ${ }^{4,5}$ and TOMISLAV OREŠIĆ 2,5 \\ ${ }^{1}$ Department of Oncological Pathology and Clinical Cytology, Ljudevit Jurak University \\ Department of Pathology, Sestre milosrdnice University Hospital Center, Zagreb, Croatia; \\ ${ }^{2}$ Department of Reconstructive Surgery, University Hospital for Tumors, \\ Sestre milosrdnice University Hospital Center, Zagreb, Croatia; \\ ${ }^{3}$ Department of Surgical Oncology, University Hospital for Tumors, \\ Sestre milosrdnice University Hospital Center, Zagreb, Croatia; \\ ${ }^{4}$ Division of Oncology and Radiotherapy, University Hospital for Tumors, \\ Sestre milosrdnice University Hospital Center, Zagreb, Croatia; \\ ${ }^{5}$ Genetic Counseling Unit, University Hospital for Tumors, \\ Sestre milosrdnice University Hospital Center, Zagreb, Croatia
}

\section{Summary}

Breast cancer (BC) represents $25 \%$ of all malignancies in Croatian women, and in $18.8 \%$ of cases, it is diagnosed before the age of 50. Croatia launched BRCA testing of people at increased family risk. Hereditary BC is mainly caused by a pathogenic mutation in the $B R C A 1$ or $B R C A 2$ gene and is a significant risk factor for developing breast and ovarian cancer.

The present study included 127 women diagnosed with BC, with a strong family history of BC and the known status of the germline mutations in the $B R C A 1 / B R C A 2$ genes. The majority of women were $B R C A 1 / 2$ mutation non-carriers, while $15.7 \%$ were $B R C A 1 / 2$ mutation carriers, and $4 \%$ had a variant of unknown significance (VUS). BRCA1/2 mutation carriers were younger than non-carriers (median 38.5 years vs. 44 years) $(\mathrm{P}=.01)$ and had tumors of higher histological grade $(\mathrm{P}<.001)$. The intrinsic subtype of $\mathrm{BC}$ differs significantly depending on the type of mutation $(\mathrm{P}<.001)$. Triple-negative $\mathrm{BC}$ prevailed $(87.5 \%)$ in BRCA1 mutation carriers, and $12.5 \%$ had a luminal B/HER2-negative BC. Four patients were $B R C A 2$ mutation carriers, and two of them had luminal B/HER2-positive BC. Most BRCA1/2 non-carriers (69.2\%) and all VUS-carriers have luminal B/HER2-negative BC.

Our results show that $B R C A 1 / 2$ mutation testing is essential for women with a family history burden. It is a piece of valuable information in breast cancer risk assessment and contributes to early diagnosis.

KEYWORDS: germline mutations, BRCA1, BRCA2, breast cancer, intrinsic subtype

\section{INTRODUCTION}

Breast cancer $(\mathrm{BC})$ is the most common cancer in women and is still one of the leading causes of death in the world. Twenty-five percent of all newly diagnosed malignancies in women were
Corresponding author: Snježana Ramić, Department of Oncological Pathology and Clinical Cytology, 'Ljudevit Jurak' University Department of Pathology, Sestre milosrdnice University Hospital Center, Ilica 197, Zagreb, Croatia.

e-mail: snjezana.ramic@gmail.com 
breast cancers, and four percent were ovarian cancers in Croatia in 2017 (1). Many genetic, environmental, and acquired factors are responsible for developing breast cancer, and early diagnosis is the key to successful treatment. The introduction of mammography screening improves early diagnosis and disease outcome. However, the screening does not include $18.8 \%$ of women in Croatia diagnosed with $\mathrm{BC}$ before the age of 50 , including $5 \%$ before the age of 40 (1).

Hereditary BC is most commonly caused by a pathogenic mutation in the BRCA1 or BRCA2 genes and is responsible for $5 \%$ to $10 \%$ of all breast cancer cases and $10 \%$ to $15 \%$ of ovarian cancer cases (2). The prevalence of individuals carrying $B R C A 1$ or $B R C A 2$ mutations in the general population is estimated to be 1 in 400 , with observed variability among populations $(3,4)$. Mutations are inherited in an autosomal dominant manner and are highly penetrant, and as such, represent a significant risk factor for the development of breast and ovarian cancer (5).

By the age of 80 , the cumulative $\mathrm{BC}$ risk in $B R C A 1$ mutation carriers is $72 \%$ and $44 \%$ for ovarian cancer, while for $B R C A 2$ mutation carriers, risks are $69 \%$ for breast cancer and $17 \%$ for ovarian cancer (5). Families with a history of breast/ ovarian cancer over several generations are predisposed to developing these diseases (6). They have different screening schedules (earlier start with ultrasound and mammography, magnetic resonance imaging interpolation, and more frequent gynecology exams)(6,7,8). Litton et al. (6) reported that in families affected by mutations in $B R C A$ genes, breast cancer in the next generation develops nearly eight years earlier than in previously affected relatives. Therefore, our hospital has introduced genetic counseling for individuals with a history of breast/ovarian cancer over several generations, according to the Clinical Practice Guidelines $(7,8)$.

We aimed to determine the proportion of BRCA1/2 mutation carriers in women with increased familial risk who are already affected by BC and to compare breast cancer histological characteristics in $B R C A 1 / 2$ mutation carriers non-carriers.

\section{PATIENTS AND METHODS}

From the $1^{\text {st }}$ of November 2017 until the $30^{\text {th }}$ of May 2020, we tested 276 women with a positive family history for germline mutations in $B R C A 1$ and $B R C A 2$ genes, according to the genetic counseling guidelines $(7,8)$.

Germline $B R C A 1$ and $B R C A 2$ mutations were analyzed in whole blood samples using next-generation sequencing on the Illumina platform and multiplex-quantitative PCR for large rearrangements. Positive results were confirmed by Sanger sequencing. Among all women tested, 132 were affected by breast cancer, nine with ovarian cancer, and five with benign breast lesions, while 108 women have been without the disease so far, and data are missing for 22 women.

The present retrospective study focused on breast cancer cases only. We collected complete data on the histological features of BC for 127 women from the clinical database. Currently, only the presence or absence of mutations in the $B R C A 1$ and $B R C A 2$ genes is clinically relevant, so we grouped statistical analysis data. Breast cancer patients with germline pathogenic mutations in any of the BRCA genes (BRCA1 or BRCA2) were defined as $B R C A 1 / 2$ mutation carriers, while patients without pathogenic mutations, including patients with a variant of unknown significance (VUS), as non-carriers.

We aimed to determine whether these subpopulations significantly differ regarding breast cancer's main histological characteristics: tumor size, histological grade, hormone receptor status, intrinsic molecular subtype, lymphovascular or perineural tumor invasion, and spread in axillary lymph nodes. We performed statistical analyses using a two-sided Fisher exact test or Chi-square test available by VassarStats online calculator (http://vassarstats.net/tab2 2 2.html) significant Pvalue at $<.05$.

\section{RESULTS}

Figure 1 displays $B R C A 1 / 2$ mutation status among 127 women affected with breast cancer (BC), for whom we collected histopathological characteristics of their cancers from the clinical database. Twenty patients $(15.7 \%)$ were carriers of the pathogenic $B R C A 1 / 2$ mutation, and most of the mutations $(80 \%)$ were in the $B R C A 1$ gene, while 107 patients were $B R C A 1 / 2$ non-carriers, including five patients ( $4 \%$ ) with VUS. 


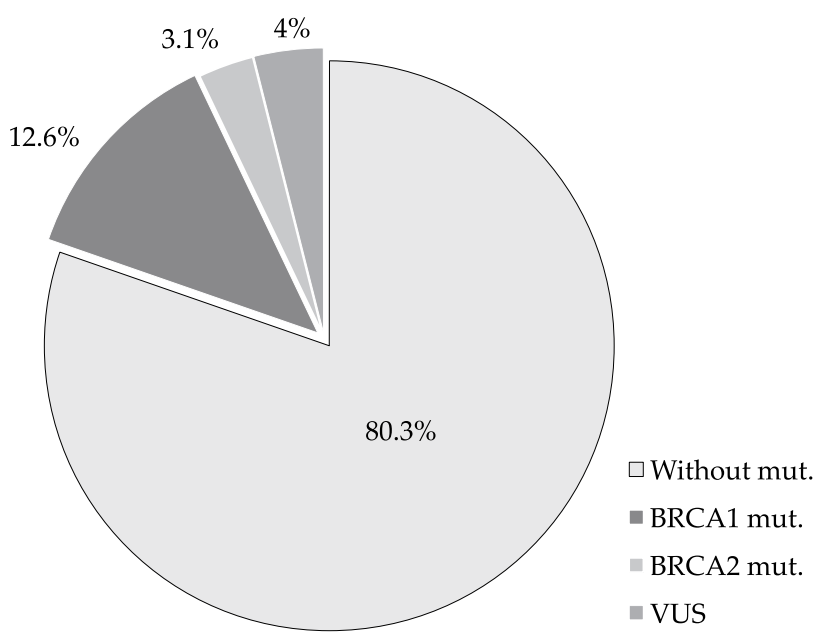

Figure 1. Germline mutation status in the BRCA1 and BRCA2 genes among 127 breast cancer patients with a strong family history of breast cancer. VUS; variant of unknown significance

Table 1 shows $B C^{\prime} s$ main characteristics in the $B R C A 1 / 2$ mutation carriers and those who are not carriers. The mean age at the time of $\mathrm{BC}$ diagnosis was $44.4 \pm 10.5$ years (median 43 years; range $24-72$ ), and $80.3 \%$ of women were younger than 50 years. The analysis showed a significant difference in the age of the patients at the time of diagnosis. Women with BRCA1/2 mutations were younger than women without mutations (median 38.5 years versus 44 years), and $60 \%$ of BRCA1/2 mutation carriers were even younger than 40 years, compared with $29 \%$ of BRCA1/2 non-carriers $(\mathrm{P}=.01)$. Also, all BRCA1/2 mutation carriers and $67.3 \%$ of non-carriers were affected by BC before the age of 50 . Results showed that BRCA1/2 mutation carriers have tumors with higher histological grade $(\mathrm{P}<.001)$ and negative estrogen receptor $(\mathrm{P}<.001)$. However, there were no differences in HER2 status $(\mathrm{P}=.183)$, positive lymph nodes $(\mathrm{P}=.998)$, or lymphovascular/perineural invasion $(\mathrm{P}=.183)$ compared to BRCA1/2 mutation non-carriers. Approximately two-thirds of patients had negative axillary lymph nodes in both groups. Tumors did not differ significantly in size relative to BRCA1/2 mutation status (median size was 15.5 $\mathrm{mm}$ in both groups; $\mathrm{P}=.608)$.

To further determine statistically significant differences in patient age at the time of diagnosis, histological grade, and status of estrogen receptors, data were stratified according to the type of mutation. The mean age at the time of $\mathrm{BC}$ diagno-
Table 1.

Differences in main histopathological characteristics of breast cancer in BRCA1/2 mutation carriers and BRCA1/2 mutation non-carriers

\begin{tabular}{|c|c|c|c|}
\hline Characteristics & $\begin{array}{l}B R C A 1 / 2 \\
\text { mutation } \\
\text { carriers } \\
\mathrm{N}=20(\%)\end{array}$ & $\begin{array}{l}\text { BRCA1/2 } \\
\text { mutation } \\
\text { non-carriers } \\
\mathrm{N}=107(\%)\end{array}$ & $\mathrm{P}^{*}$ \\
\hline $\begin{array}{l}\text { Age of patients (years) } \\
\quad \leq 40 \\
>40\end{array}$ & $\begin{array}{l}12(60.0) \\
8(40.0) \\
\end{array}$ & $\begin{array}{l}31(28.9) \\
76(71.1) \\
\end{array}$ & .01 \\
\hline $\begin{array}{l}\text { Size of tumour }(\mathrm{mm}) \\
\quad \leq 20 \\
>20\end{array}$ & $\begin{array}{l}12(60.0) \\
8(40.0)\end{array}$ & $\begin{array}{l}72(67.3) \\
35(32.7) \\
\end{array}$ & .608 \\
\hline $\begin{array}{l}\text { Histological grade } \\
\text { I/II } \\
\text { III }\end{array}$ & \begin{tabular}{|l}
$2(10.0)$ \\
$18(90.0)$ \\
\end{tabular} & $\begin{array}{l}62(57.9) \\
45(42.1) \\
\end{array}$ & $<.001$ \\
\hline $\begin{array}{l}\text { Estrogen receptor } \\
\text { Positive } \\
\text { Negative }\end{array}$ & $\begin{array}{l}5(25.0) \\
15(75.0)\end{array}$ & $\begin{array}{l}90(84.1) \\
17(15.9)\end{array}$ & $<.001$ \\
\hline $\begin{array}{l}\text { HER2 status } \\
\text { Positive } \\
\text { Negative }\end{array}$ & $\begin{array}{l}2(10.0) \\
18(90.0)\end{array}$ & $\begin{array}{l}23(21.5) \\
84(78.5) \\
\end{array}$ & .36 \\
\hline $\begin{array}{l}\text { Lymphovascular or } \\
\text { perineural invasion } \\
\text { Present } \\
\text { Absent } \\
\text { Unknown } \\
\end{array}$ & $\begin{array}{l}6(46.2) \\
7(53.8) \\
7\end{array}$ & $\begin{array}{l}18(32.7) \\
37(67.3) \\
52\end{array}$ & .183 \\
\hline $\begin{array}{l}\text { Lymph node status } \\
\text { Positive } \\
\text { Negative } \\
\text { Unknown }^{\dagger}\end{array}$ & $\begin{array}{l}6(33.3) \\
12(66.7) \\
2\end{array}$ & $\begin{array}{l}32(33.7) \\
60(66.3) \\
15\end{array}$ & .998 \\
\hline
\end{tabular}

* Two-sided Fisher exact test, statistically significant P-values are in bold; t Cases with unknown parameters were excluded from the analysis

sis differed significantly according to BRCA1/2 mutation status, as presented in Figure 2. Women bearing $B R C A 1$ and $B R C A 2$ mutation were diagnosed before the age of $40(38.3 \pm 7.2$ and $35 \pm 4.9$ years) while women with VUS were at similar age at the time of diagnosis as $B R C A 1 / 2$ non-carriers (44.6 \pm 4.1 years and $45.8 \pm 10.9$ years $)(\mathrm{P}=0.008)$. $\mathrm{Pa}$ tients with either $B R C A 1$ or $B R C A 2$ mutations had predominantly histological grade III cancers, compared with BRCA1/2 mutation non-carriers and VUS-carriers $(\mathrm{P}=.001)$ (Figure 3 ).

Overall, we recorded $19.6 \%$ of a triple-negative intrinsic subtype of breast cancer (TNBC), luminal profile in $60.7 \%$ (luminal A in $15 \%$, luminal $\mathrm{B}$ in $45.7 \%$ ), luminal B/HER2-positive in $15 \%$, and HER2-enriched intrinsic type (with negative hormone receptors) in $4.7 \%$.

As presented in Figure 4, TNBC prevailed $(87.5 \%)$ in $B R C A 1$ mutation carriers, $12.5 \%$ were luminal B/HER2-negative, and none were HER2- 


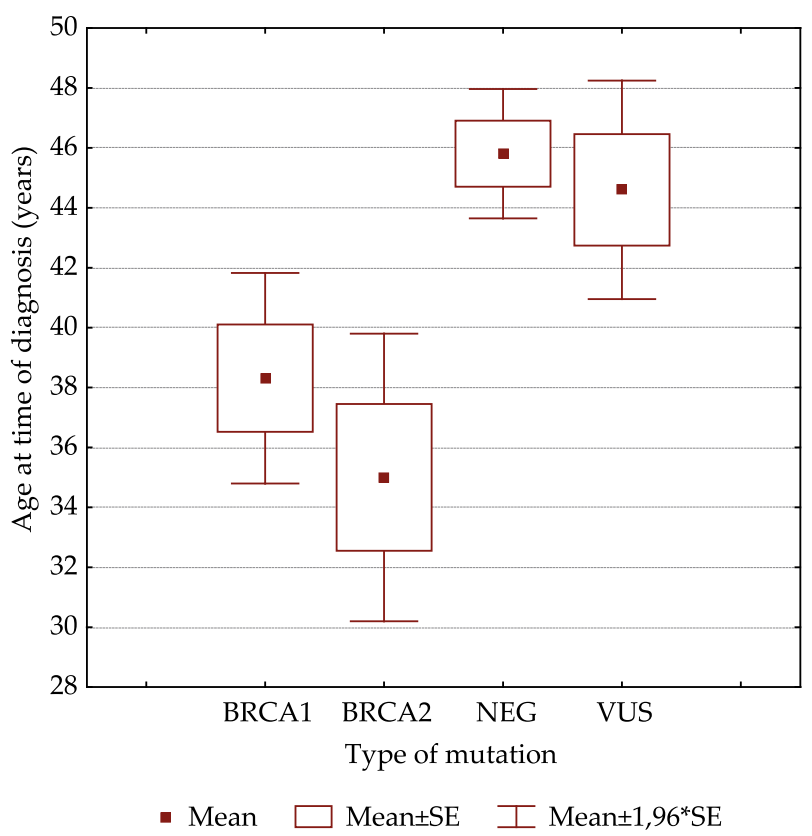

Figure 2. The mean age at the time of breast cancer diagnosis according to BRCA1/2 mutation status. VUS, variant of unknown significance; NEG, patients without pathogenic BRCA1/2 mutations $(P=.008)$

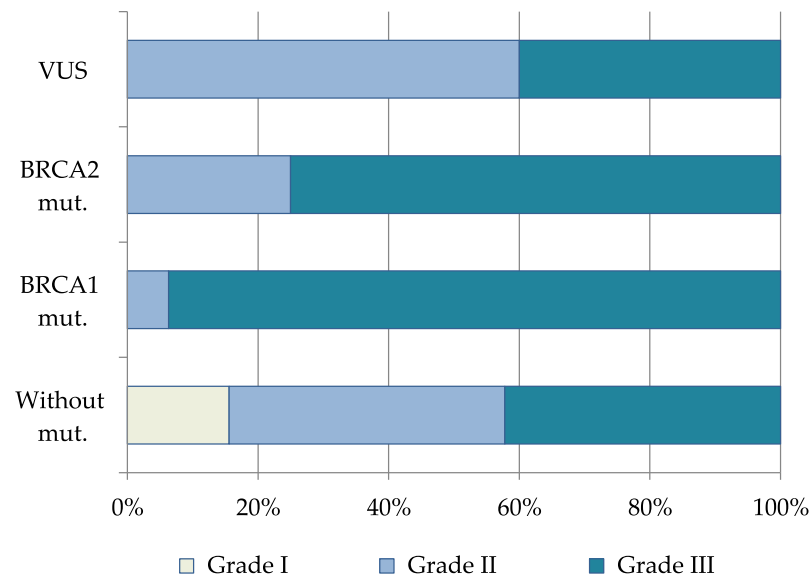

Figure 3. Incidence of the histological grade of breast cancer according to BRCA1/2 mutation status ( $\chi 2=15,45 ; P=.001$ )

enriched. Only four patients (3.1\%) were BRCA2mutation carriers. Two of them had luminal B/ HER2-positive BC (50\%), and one each had TNBC and luminal A/HER2-negative.

In patients without $B R C A 1 / 2$ mutations, luminal/HER2-negative profile prevailed (69.2\%), TNBC was diagnosed in only $9.8 \%$, luminal B/ HER2-positive in 16.7\%, and HER2-enriched type

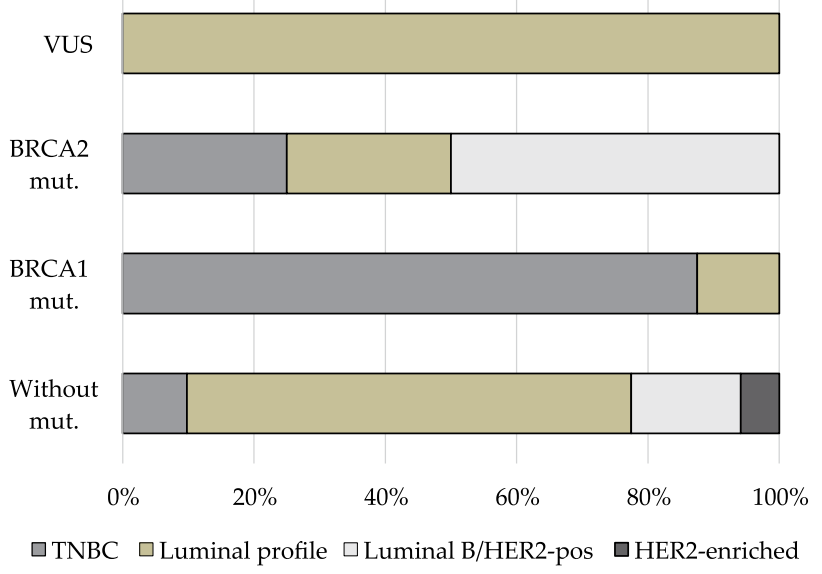

Figure 4. Incidence of intrinsic subtypes of breast cancer according to BRCA1/2 mutation status $(\chi 2=46.18 ; P<.001)$; TNBCtriple-negative breast cancer; Luminal profile includes both luminal $A$ and luminal $B$

in $5.8 \%$ of cases. Besides, all five patients (4\%) with VUS have an intrinsic luminal profile with negative HER2.

\section{DISCUSSION}

Our results show that breast cancer (BC) histopathological characteristics, depending on the status of BRCA1/2 mutations, are similar to published data. Most women with a severe family history who are already affected by $\mathrm{BC}$ are $B R C A 1 / 2$ mutation non-carriers, while $15.7 \%$ of women are carriers of $B R C A 1 / 2$ mutations. The literature reported that between $12 \%$ and $25.64 \%$ of women with familial breast cancer are carriers of $B R C A 1 / 2$ mutations (9-13). Minor differences can be explained by the relatively small cohort in our study, especially given the small percentage of $B R C A 2$ mutations.

Over $70 \%$ of women in our cohort were younger than 50 years. The median age at diagnosis was 43 years. All women with $B R C A 1 / 2$ mutations were diagnosed with $B C$ before 40 , while women without $B R C A 1 / 2$ mutations were slightly older (mean $45.8 \pm 10.9$ years). Regardless of the BRCA1/2 mutation status, women with hereditary or familial BC become ill much earlier than the incidence of sporadic BC that occurs after age 60 (14). This result was expected because some of the criteria needed for testing are the personal history of triple-negative breast cancer (TNBC) before age 
60 or any type of breast cancer before age $45(7,8)$. Other authors also reported a high BC incidence around age 40 in $B R C A 1 / 2$ mutation carriers (1517). The literature emphasizes that younger women have more aggressive cancer and lower survival rates. A positive family history of $\mathrm{BC}$ is a very strong risk factor for women under 35 (relative risk $=3.22)(18)$. They reported a $39 \%$ higher risk of death in women affected with BC before 40 . However, recent articles report a similar prognosis of breast cancer in BRCA1/2 mutation carriers in sporadic breast cancer, although there is still a disagreement about this (13,19-22). A large metaanalysis by Barreta et al. (23) showed that carriers of the BRCA1 mutation, but not BRCA2, have a higher overall survival risk than non-carriers. The same analysis, and a few others, reveals that the presence of the BRCA1/2 mutations in TNBC correlates with better overall survival $(13,23,24)$. Due to the known BRCA1/2 mutation-positive status, patients were diagnosed at an earlier stage of the disease, and TNBCs received adequate neoadjuvant therapy (24). BRCA1 mutation carriers have enhanced sensitivity to neoadjuvant chemotherapy with cytotoxic drugs (24). Thus, those patients had good outcomes and more significant overall and disease-free survival $(17,19)$.

BRCA1/2 mutation carriers have less differentiated cancers. Possibly due to a small cohort, we did not detect significantly larger tumors or more aggressive biology, e.g., with lymphovascular/perineural or lymph node invasion compared to non-carriers. Some published results showed no difference in tumor size or positive lymph node status $(12,24,25)$. In contrast, others recorded a significant difference in the number of positive lymph nodes or lymphovascular/perineural invasion $(9,13,17,18)$.

Our results showed a high incidence of TNBC in $B R C A 1 / 2$ mutation carriers, predominantly in $B R C A 1$-mutation carriers $(87.5 \%)$, while the average incidence in sporadic breast cancer was about 10\% (14). HER2-positive breast cancers were rare in BRCA1/2 mutation carriers. Only two women who had luminal B/HER2-positive tumors had mutations in the BRCA2 gene, while none of the $B R C A 1$ mutation carriers had a HER2-positive tumor, similar to the results of Fountzilas et al. (9). However, most papers agree on the percentage of TNBC, which decreases with age at diagnosis in $B R C A 1$ mutation carriers and increases with age in BRCA2 mutation carriers $(11,12)$. Moreover, mutations in the BRCA1 gene are associated with a high histological grade, hormone receptor-negative, and basal gene expression profile (CK5/6and CK14-positive), while mutations in the BRCA2 gene usually shows an inverted histological picture and luminal molecular profile $(16,17,22,26,27)$.

Family history increase the risk of breast/ ovarian cancer because even in the $B R C A 1 / 2$ noncarriers group, we found almost $70 \%$ of patients affected by $B C$ before the age of 50 . On the other hand, BC in BRCA1/2 non-carriers showed immunophenotypes similar to sporadic cancers, with predominantly luminal features, despite family history. They were TNBC in less than $10 \%$, with a positive estrogen receptor in over $80 \%$ of tumors and HER2-positive in about $20 \%$, as previously reported in sporadic cancers (14).

Patients with VUS carry a change that is not defined as pathological so far and show characteristics of proven $B R C A 1 / 2$ non-carriers. All patients with VUS had only luminal/HER-negative intrinsic subtype with a similar age of disease as $B R C A 1 / 2$ non-carriers. However, literature reports that $B R C A 1 / 2$ mutation non-carriers from families with a strong history of $B C$ might harbor mutations in other high- and moderate-penetrance genes associated with BC risk $(19,22,28)$.

According to the study by Brozek et al. (29), half of the mutation carriers lack an evident family history and, therefore, will not be detected as breast-cancer families by the current selection criteria. Prediction algorithms for the BRCA1/2 mutation carriers based on their family history can calculate breast and ovarian cancer risk. Based on probability models, women who have a $5 \%$ probability of $B R C A 1 / 2$ pathogenic variant qualify for genetic testing, and those with $2.5 \%$ probability can be considered for testing (7). The NCCN guidelines emphasize the need for multiple gene testing only for clinically actionable genes, as more information adds more complexity and difficulty to risk management decisions. When nine genes were tested in multi-gene panels, Yadav et al. (28) detected almost $30 \%$ of women with pathogenic mutations compared to $13 \%$ of mutations detected when tested for BRCA1/2 genes only.

According to Ruddy et al. (31), nearly $80 \%$ of breast cancers in young women are diagnosed as self-finding. There is no effective breast cancer screening tool for women under 40 . The dense 
breast tissue prevents routine mammography from being a useful screening tool. In BRCA1/2 mutation carriers, breast cancer clinical examinations should begin earlier and more frequently than in other women. They should also be aware of BC's warning signs, conduct regular annual ultrasound examinations from 25 years of age, and an MRI alone until 40 (7). Men with the BRCA1/2 mutation should also have an annual clinical breast examination.

Further monitoring of our patients will provide more information about tumor biology and patients' survival factors.

\section{CONCLUSION}

Our results show that testing for $B R C A 1 / 2$ mutations is essential for women who meet the criteria according to the guidelines and can play a vital role in assessing $\mathrm{BC}$ risk and contribute to early diagnosis and possibly better treatment options.

\section{Ethics approval and patient consent for publication}

Not applicable.

\section{Competing interests} declare.

Authors do not have competing interests to

\section{REFERENCES}

1. Šekerija M, Bubanović L, Novak P, Veltruski J, Glibo M, Stavinoha M, et al. Registar za rak Republike Hrvatske. Incidencija raka u Hrvatskoj 2017. Hrv zavod za javno Zdr. 2020;Bilten 42(42).

2. Mehrgou A, Akouchekian M. The importance of BRCA1 and BRCA2 genes mutations in breast cancer development. [Internet]. Med J Islam Repub Iran. 2016;30(1):369. [cited 2020 Sep 22]. Available from: http://mjiri.iums.ac.ir

3. Thompson ER, Rowley SM, Li N, McInerny S, Devereux L, Wong-Brown MW, et al. Panel testing for familial breast cancer: Calibrating the tension between research and clinical care. J Clin Oncol. 2016;34 (13):1455-9.

4. Maxwell KN, Domchek SM, Nathanson KL, Robson ME. Population frequency of germline BRCA1/2 mutations. J Clin Oncol. 2016;34:4183-5.

5. Kuchenbaecker KB, Hopper JL, Barnes DR, Phillips KA, Mooij TM, Roos-Blom MJ, et al. Risks of breast, ovarian, and contralateral breast cancer for BRCA1 and BRCA2 mutation carriers. JAMA. 2017;317(23): 2402-16.

6. Litton JK, Ready K, Chen H, Gutierrez-Barrera A, Etzel CJ, Meric-Bernstam F, et al. Earlier age of onset of BRCA mutation-related cancers in subsequent generations. Cancer. 2012;118(2):321-5.

7. National Comprehensive Cancer Network. Clinical practice guidelines in oncology. Genetic/familial highrisk assessment: Breast, ovarian, and pancreatic cancer. [Internet]. NCCN. Version 1.2021. [cited 2020 Sep 22]. Available from: https://www.nccn.org/professionals/physician_gls/pdf/genetics_bop.pdf

8. Borovečki A, Braš $\mathrm{M}$, Brkljačić $\mathrm{B}$, Canki-Klain $\mathrm{N}$, Plavetić ND, Grahovac B, et al. Guidelines for genetic counseling and testing for hereditary breast and ovarian cancer. Lijec Vjesn. 2017;139(5-6):107-17.

9. Fountzilas E, Konstantopoulou I, Vagena A, Apostolou P, Papadimitriou C, Christodoulou C, et al. Pathology of BRCA1- and BRCA2-associated breast cancers: Known and less known connections. Clin Breast Cancer. 2020;20(2):152-9.

10. Atchley DP, Albarracin CT, Lopez A, Valero V, Amos CI, Gonzalez-Angulo AM, et al. Clinical and pathologic characteristics of patients with BRCA-positive and BRCA-negative breast cancer. J Clin Oncol. 2008; 26(26):4282-8.

11. Emborgo TS, Saporito D, Muse KI, Barrera AMG, Litton JK, Lu KH, et al. Prospective evaluation of universal BRCA testing for women with triple-negative breast cancer. JNCI Cancer Spectr. 2020;4(2):2-7.

12. Jouhadi H, Tazzite A, Azeddoug H, Naim A, Nadifi S, Benider A. Clinical and pathological features of BRCA1/2 tumors in a sample of high-risk Moroccan breast cancer patients Cancer. BMC Res Notes. 2016; 9(1):1-7.

13. Copson ER, Maishman TC, Tapper WJ, Cutress RI, Greville-Heygate S, Altman DG, et al. Germline BRCA mutation and outcome in young-onset breast cancer (POSH): a prospective cohort study. Lancet Oncol. 2018;19(2):169-80.

14. Ramić S, Balja MP, Ramljak V, Zadro S, Kirac I, Orešić $\mathrm{T}$, et al. Histopathological features of breast cancer from 2005 to 2019 in a single center in Croatia: An overview of changes following the introduction of mammography screening. Libr Oncol. 2020;48(1): 13-9.

15. Ha SM, Chae EY, Cha JH, Kim HH, Shin HJ, Choi WJ. Association of BRCA mutation types, imaging features, and pathologic findings in patients with breast cancer with BRCA1 and BRCA2 Mutations. Am J Roentgenol [Internet]. 2017;209(4):920-8.

16. Larsen MJ, Kruse TA, Tan Q, Lænkholm AV, Bak M, Lykkesfeldt AE, et al. Classifications within Molecular Subtypes Enables Identification of BRCA1/BRCA2 Mutation Carriers by RNA Tumor Profiling. PLoS One [Internet]. 2013;8(5):e64268. DOI: 10.1371/journal. pone. 0064268 
17. Sønderstrup IMH, Jensen MBR, Ejlertsen B, Eriksen JO, Gerdes AM, Kruse TA, et al. Subtypes in BRCAmutated breast cancer. Hum Pathol. 2019;84:192-201.

18. Anders CK, Johnson R, Litton J, Phillips M, Bleyer A. Breast Cancer Before Age 40 Years. Semin Oncol. 2009; 36(3):237-49.

19. Godet I, M. Gilkes D. BRCA1 and BRCA2 mutations and treatment strategies for breast cancer. [Internet]. Integr Cancer Sci Ther. 2017;4(1):10.15761/ICST.1000 228. DOI: 10.15761/ICST.1000228.

20. Templeton AJ, Gonzalez LD, Vera-Badillo FE, Tibau A, Goldstein R, Šeruga B, et al. Interaction between hormonal receptor status, age and survival in patients with BRCA1/2 germline mutations: A systematic review and meta-regression. PLoS One. 2016;11(5):1-11.

21. Larson K, Wang Y, Finke K, O'Dea A, Khan Q, Nye L, et al. Impact of germline BRCA mutation status on survival in women with metastatic triple negative breast cancer. 2019; 7(4): 81-6.

22. Tung NM, Boughey JC, Pierce LJ, Robson ME, Bedrosian I, Dietz JR, et al. Management of Hereditary Breast Cancer: American Society of Clinical Oncology, American Society for Radiation Oncology, and Society of Surgical Oncology Guideline. J Clin Oncol. 2020; 38(18):2080-106.

23. Baretta Z, Mocellin S, Goldin E, Olopade OI, Huo D. Effect of BRCA germline mutations on breast cancer prognosis: A systematic review and meta-analysis. [Internet]. Med (United States). 2016;95(40). Available from: https://pubmed.ncbi.nlm.nih.gov/27749552/ [cited 2020 the 7 th of October]
24. Talhouet S De, Peron J, Vuilleumier A, Friedlaender A, Viassolo V, Ayme A, et al. Clinical outcome of breast cancer in carriers of BRCA1 and BRCA2 mutations according to molecular subtypes. Sci Rep. 2020;10(1): 1-9.

25. Macedo GS, Alemar B, Ashton-Prolla P. Reviewing the characteristics of BRCA and PALB2-related cancers in the precision medicine era. Genet Mol Biol. 2019;42 (1):215-31.

26. Chen H, Wu J, Zhang Z, Tang Y, Li X, Liu S, et al. Association between BRCA status and triple-negative breast cancer: A meta-analysis. Front Pharmacol. 2018; 9:1-8.

27. Ibarra JA. Pathology of BRCA Tumors. In: Managing BRCA Mutation Carriers [Internet]. Cham: Springer International Publishing; 2017. p. 89-117. [cited 2020 the 7th of October]. Available from: http://link.springer.com/10.1007/978-3-319-59198-8_6

28. Yadav S, Hu C, Hart SN, Boddicker N, Polley EC, Na $\mathrm{J}$, et al. Evaluation of germline genetic testing criteria in a hospital-based series of women with breast cancer. J Clin Oncol. 2020;38(13):1409-18.

29. Brozek I, Ratajska M, Piatkowska M, Kluska A, Balabas A, Dabrowska M, et al. Limited significance of family history for presence of BRCA1 gene mutation in Polish breast and ovarian cancer cases. Fam Cancer. 2012;11(3):351-4.

30. Ruddy KJ, Gelber S, Tamimi RM, Schapira L, Come $\mathrm{SE}$, Meyer ME, et al. Breast cancer presentation and diagnostic delays in young women. Cancer. 2014; 120:20-5.

Sažetak

\title{
KARAKTERISTIKE RAKA DOJKE OVISNO O STATUSU MUTACIJA U GENIMA BRCA1 i BRCA2 U HRVATSKOJ
}

\author{
S. Ramić, G. Alfier, I. Kirac, I. Milas, P. Vuković i T. Orešić
}

Rak dojke predstavlja 25\% svih zloćudnih bolesti u žena u Hrvatskoj, a u 18,8\% slučajeva dijagnosticira se prije 50 . godine života. Nasljedni rak dojke uglavnom je uzrokovan patogenom mutacijom u genima BRCA1 ili BRCA2 te predstavlja glavni čimbenik rizika za razvoj raka dojke i jajnika. Stoga je Hrvatska pokrenula testiranje mutacija u genima BRCA1 i BRCA2 kod osoba koje, prema smjernicama za genetičko testiranje, imaju povećani obiteljski rizik.

Ovo retrospektivno istraživanje obuhvatilo je 127 žena s pozitivnom obiteljskom anamnezom i utvrđenim statusom mutacija u genima BRCA1 i BRCA2, kojima je dijagnosticiran rak dojke. Većina žena nisu bile nositeljice mutacija u genima BRCA1 ili BRCA2 (BRCA1/2), dok je 15,7\% bilo nositeljica mutacije BRCA1/2, a 4\% je imalo varijantu nepoznatog značaja (VUS). Nositeljice mutacije BRCA1/2 bile su mlađe od ne-nositeljica (medijan 38,5 godina u odnosu na 44 godine) (P=.01) te su imale tumore višeg histološkog gradusa $(\mathrm{P}<.001)$. Intrinzični podtip raka dojke značajno se razlikuje ovisno o tipu mutacije $(\mathrm{P}<.001)$. Trostruko negativni podtip raka dojke prevladao je u nositeljica mutacija u BRCA1 (87,5\%), a 12,5\% imalo je luminalni B/HER2-negativni podtip. Četiri bolesnice bile su nositeljice mutacija u BRCA2 genu, od kojih dvije s luminalnim B/HER2-pozitivim rakom dojke. Većina bolesnica (69,2\%) koje nisu nositeljice patoloških mutacija BRCA1/2 i sve one s VUS imale su luminalni B/HER2-negativni podtip raka dojke.

Naši rezultati pokazuju da je testiranje mutacija u genima BRCA neophodno za žene s opterećenom obiteljskom anamnezom jer može igrati vitalnu ulogu u procjeni rizika od raka dojke i doprinjeti ranoj dijagnozi.

KLJUČNE RIJEČI: nasljedne mutacije, BRCA1, BRCA2, rak dojke, intrinzični podtip 